\title{
Living with Subject Indicator
}

National Cancer Institute

\section{Source}

National Cancer Institute. Living with Subject Indicator. NCI Thesaurus. Code C135502.

An indication as to whether the associated person is living with the subject. 